\title{
EVALUATION OF HOMOCYSTEINE AND FOLIC ACID LEVELS IN PREGNANCY LOSS
}

\author{
E. Premakumari ${ }^{1}$, N. I. Sowganthika², P. Sowkanthika ${ }^{3}$
}

${ }_{1}^{1}$ Associate Professor, Department of Obstetrics and Gynaecology, Institute of Social Obstetrics and Kasturba Gandhi Hospital for Women and Children, Madras Medical College, Chennai, Tamilnadu, India.

${ }_{2}^{2}$ Assistant Professor, Department of Obstetrics and Gynaecology, Government Medical College, Omandurar Government Estate, Omandurar Medical College, Chennai, Tamilnadu, India.

${ }^{3}$ Final Year MBBS Student, Father Muller Medical College, Mangalore, Karnataka, India.

ABSTRACT
BACKGROUND
pyperhomocysteinaemia is associated with several pregnancy related complications such as recurrent pregnancy loss,
in pregnancy.
The aim of this study was to assess the relationship of fasting total plasma homocysteine level and serum folic acid level with
pregnancy loss.

\section{MATERIALS AND METHODS}

Participants were categorised into cases (Women with Pregnancy Loss) and controls (Normal Antenatal Women) with N=100 each. Enzymatic photometric estimation of fasting total plasma homocysteine and folic acid levels was done. Data was statistically analysed.

\section{RESULTS}

The analysis by t-test showed that the mean fasting total plasma homocysteine level was statistically higher in cases (13.85 \pm 12.04 $\mu \mathrm{mol} / \mathrm{L})$ as compared to controls $(10.19 \pm 2.57 \mu \mathrm{mol} / \mathrm{L}), \mathrm{p}<0.05$. The mean folic acid level was significantly lower in patients with pregnancy loss $(11.85 \pm 5.13 \mathrm{ng} / \mathrm{mL})$ as compared to controls $(13.92 \pm 3.73 \mathrm{ng} / \mathrm{mL}), \mathrm{p}<0.001$.

\section{CONCLUSION}

The fasting total plasma homocysteine level was significantly higher and folic acid level was significantly lower in women with pregnancy loss. The difference was more in women who experienced pregnancy loss four times.

\section{KEY WORDS}

Homocysteine, Folic Acid, Pregnancy Loss.

HOW TO CITE THIS ARTICLE: Premakumari E, Sowganthika NI, Sowkanthika P. Evaluation of homocysteine and folic acid levels in pregnancy loss. J. Evolution Med. Dent. Sci. 2018;7(25):2926-2930, DOI: 10.14260/jemds/2018/659

\section{BACKGROUND}

35 per 1000 women experience pregnancy loss annually. ${ }^{1}$ The reason for pregnancy loss are varied including anatomic, endocrine, thrombotic, chromosomal, biochemical and immunological factors in addition to interaction of several genetic and environmental factors.

Homocysteine is an amino acid, which is potentially embryotoxic when present in abnormally increased concentrations. It also decreases foetal viability. Several pregnancy related complications such as recurrent pregnancy loss, pre-eclampsia, abruption, growth restriction, intrauterine death, still births, thromboembolic episodes and neural tube defects have been seen in hyperhomocysteinaemia. ${ }^{2}$ The micronutrient dependent homocysteine metabolism can become faulty and result in hyperhomocysteinaemia in the presence of Vitamin B complex deficiency and gene polymorphisms. ${ }^{3}$

'Financial or Other Competing Interest': None.

Submission 11-05-2018, Peer Review 02-06-2018,

Acceptance 09-06-2018, Published 18-06-2018.

Corresponding Author:

Dr. E. Premakumari,

K-2, Parasa Apartments, Shanthi Colony,

Jeevarathinam Nagar, Adyar,

Chennai-600020, Tamilnadu, India.

E-mail: drprema2016@gmail.com

DOI: $10.14260 /$ jemds $/ 2018 / 659$
Folic acid is a part of the vitamin B periconceptional supplement. It has a foetus-protective role, the deficiency of which results in pronounced neural tube defects and placental complications. ${ }^{4}$

\section{Aims and Objectives}

In the current study, we aim to assess the relationship of fasting total plasma homocysteine level and serum folic acid level with pregnancy loss.

\section{MATERIALS AND METHODS \\ Study Design and Setting}

This case-control observational study was done in Government RSRM Lying-In Hospital, Stanley Medical College, Chennai between November 2014 and November 2015 in the Department of Obstetrics and Gynaecology.

\section{Sample Size}

The last five years, 2499 pregnancy loss cases were encountered in this referral centre as per the hospital records of the last 5 years. A minimum of 93 cases were required for the study considering a confidence level of $95 \%$ and a confidence interval of $10 \%$. We have included 100 cases in the study. Equal numbers of participants were taken as controls. Hence, the study consisted of 200 women grouped into cases $(\mathrm{N}=100)$ and controls $(\mathrm{N}=100)$. 


\section{Study Population}

Study was commenced after Institutional Ethics Committee approval was obtained. The case group consisted of patients with one or multiple pregnancy losses attending the antenatal outpatient department. The controls were antenatal women with a minimum gestational age of 13 weeks who have at least one living child and no history of previous abortion. Women with chronic medical disorders, endocrine dysfunction, neurological dysfunction, ectopic pregnancy, molar pregnancy and organic cause for pregnancy loss were excluded. For this purpose, women attending antenatal clinic in the Department of Obstetrics and Gynaecology including the referred cases were enrolled in the study after obtaining informed consent. A detailed obstetric assessment was done to rule out cases not meeting the inclusion criteria. Only the patients who met the inclusion criteria were subjected to further evaluation in terms of folic acid and plasma homocysteine levels. The population consisted of women mainly from in and around Tamilnadu.

\section{Procedure}

The baseline patient details and obstetric details were recorded. $5 \mathrm{~mL}$ of blood (venous) was drawn under aseptic care after 10 hours of fasting. The samples were analysed for fasting total plasma homocysteine levels and serum folic acid levels. The estimation was by automated enzymatic photometric method.

\begin{tabular}{|c|c|}
\hline Quantity & Inference \\
\hline$<15 \mu \mathrm{mol} / \mathrm{L}$ & Normal \\
\hline $15-30 \mu \mathrm{mol} / \mathrm{L}$ & Mild increase \\
\hline $30-100 \mu \mathrm{mol} / \mathrm{L}$ & Moderate increase \\
\hline$>100 \mu \mathrm{mol} / \mathrm{L}$ & Severe increase \\
\hline \multicolumn{2}{|c|}{ Homocysteine Categories } \\
\hline
\end{tabular}

\begin{tabular}{|c|c|}
\hline Quantity & Inference \\
\hline $2-20 \mathrm{ng} / \mathrm{mL}$ & Normal \\
\hline$<2 \mathrm{ng} / \mathrm{mL}$ & Decreased \\
\hline \multicolumn{2}{|c|}{ Folic Acid Levels } \\
\hline
\end{tabular}

The patients with elevated homocysteine and decreased folic acid levels were treated with folic acid and multivitamin tablets.

\section{Statistical Analysis}

The data was analysed using SPSS software version 20.0. The samples were first assessed for significance using Chi-square test. The samples were then analysed for significance using independent sample t-test including Levene's test for equality of variance and T-test for equality of means. One-Way ANOVA and Post Hoc test was used for analysis of descriptives and multiple comparisons respectively with $\alpha=0.05$. Results were expressed as mean \pm standard deviation and in percentages. $P$ value of $<0.05$ was considered significant and $p<0.001$ was considered highly significant.

\section{RESULTS}

The present study conducted on 200 women demonstrated the following results. The case group included 24 (24\%) women with single pregnancy loss, 32 (32\%) women with two pregnancy loss, 24 (24\%) with three pregnancy loss and $20(20 \%)$ women with four pregnancy loss. The mean age was $25.76 \pm 4.76$ years in cases $26.54 \pm 4.40$ years in controls and no significant age difference was observed between the groups.

\begin{tabular}{|c|c|c|c|c|c|}
\hline & N & $\begin{array}{c}\text { Mean } \\
\text { (In Years) }\end{array}$ & $\begin{array}{c}\text { Standard } \\
\text { Deviation }\end{array}$ & T value & P \\
\hline Cases & 100 & 25.76 & 4.27 & \multirow{2}{*}{-1.272} & 0.205 \\
\hline Controls & 100 & 26.54 & 4.40 & & \\
\hline
\end{tabular}

Legend 1. Mean difference between the groups does not show any significant difference

Table 1. Descriptive Statistics and Mean Difference between Groups with Respect to Age

\begin{tabular}{|c|c|c|c|c|c|c|c|}
\hline & 옳 & z & 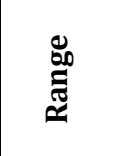 & $\sum_{\bar{\pi}}^{\tilde{\pi}}$ & 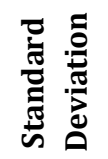 & $\begin{array}{l}\frac{0}{3} \\
\frac{\pi}{2} \\
E\end{array}$ & $\frac{0}{3}$ \\
\hline \multirow{2}{*}{$\begin{array}{l}\text { Homo- } \\
\text { cysteine }\end{array}$} & Cases & 100 & $\begin{array}{c}3.6- \\
102.2 \\
\mu \mathrm{mol} / \mathrm{L}\end{array}$ & $\begin{array}{c}13.85 \\
\mu \mathrm{mol} / \mathrm{L}\end{array}$ & $\begin{array}{c}12.04 \\
\mu \mathrm{mol} / \mathrm{L}\end{array}$ & \multirow{2}{*}{2.973} & \multirow[t]{2}{*}{.003} \\
\hline & Controls & 100 & $\begin{array}{l}2.1-19.9 \\
\mu \mathrm{mol} / \mathrm{L}\end{array}$ & $\begin{array}{c}10.19 \\
\mu \mathrm{mol} / \mathrm{L}\end{array}$ & $\begin{array}{c}2.57 \\
\mu \mathrm{mol} / \mathrm{L}\end{array}$ & & \\
\hline \multirow{2}{*}{$\begin{array}{l}\text { Folic } \\
\text { Acid }\end{array}$} & Cases & 100 & $\begin{array}{c}4.3-14.9 \\
\mathrm{ng} / \mathrm{mL}\end{array}$ & $\begin{array}{c}11.85 \\
\mathrm{ng} / \mathrm{mL}\end{array}$ & $\begin{array}{c}5.13 \\
\mathrm{ng} / \mathrm{mL}\end{array}$ & \multirow{2}{*}{3.262} & \multirow{2}{*}{.001} \\
\hline & Controls & 100 & $\begin{array}{l}7.6-19.6 \\
\mathrm{ng} / \mathrm{mL}\end{array}$ & $\begin{array}{c}13.92 \\
\mathrm{ng} / \mathrm{mL}\end{array}$ & $\begin{array}{c}3.73 \\
\mathrm{ng} / \mathrm{mL}\end{array}$ & & \\
\hline & able 2. & & of Homc & $\begin{array}{l}\text { ocystein } \\
\text { nd Cont }\end{array}$ & $\begin{array}{l}\text { and } F c \\
\text { ols }\end{array}$ & & \\
\hline
\end{tabular}

Of the 200 patients assessed for fasting total plasma homocysteine levels all the 100 women in the control group had normal levels, whereas in the case group 76 women had normal levels, 15 women showed mild increase, 8 women showed moderate increase and 1 woman showed severe increase (Figure 1).

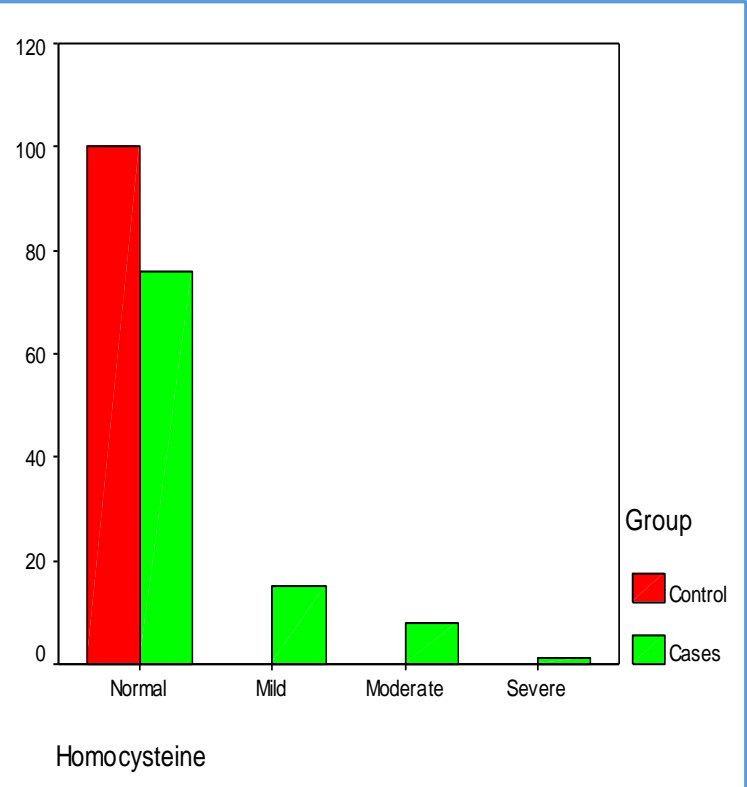

Figure 1. Categories of Homocysteine Level (Normal is < 15 $\mu \mathrm{mol} / \mathrm{L}$, Mild Increase is 15 - $30 \mu \mathrm{mol} / \mathrm{L}$, Moderate Increase is 30 - $100 \mu \mathrm{mol} / \mathrm{L}$, Severe Increase is $>100$ $\mu \mathrm{mol} / \mathrm{L}$ ) 
The analysis by Independent samples t-test showed that the mean fasting total plasma homocysteine level was statistically higher in patients with pregnancy loss $(13.85 \pm 12.04 \mu \mathrm{mol} / \mathrm{L})$ as compared to controls $(10.19 \pm 2.57 \mu \mathrm{mol} / \mathrm{L}), \mathrm{p}<0.05$ (Table 2$)$. There was a highly significant statistical difference in the fasting homocysteine levels as determined by one-way ANOVA F $(3,96)$ $=7.638, \mathrm{P}=0.000$ (Table 3 ).

\begin{tabular}{|c|c|c|c|c|c|c|c|c|}
\hline \multirow{2}{*}{$\begin{array}{l}\text { Number of } \\
\text { Pregnancy } \\
\text { Loss }\end{array}$} & \multirow{2}{*}{$\begin{array}{l}\text { No. of } \\
\text { Cases }\end{array}$} & \multirow{2}{*}{$\begin{array}{c}\text { Mean } \\
\text { Homocysteine } \\
\text { Levels }(\mu \mathrm{mol} / \mathrm{L})\end{array}$} & \multirow{2}{*}{$\begin{array}{c}\text { Std. } \\
\text { Deviation } \\
(\mu \mathrm{mol} / \mathrm{L})\end{array}$} & \multirow{2}{*}{$\begin{array}{l}\text { Std. } \\
\text { Error }\end{array}$} & \multicolumn{2}{|c|}{$\begin{array}{c}\text { 95\% Confidence } \\
\text { Interval for Mean }\end{array}$} & \multirow{2}{*}{$\begin{array}{l}\text { Minimum } \\
(\mu \mathrm{mol} / \mathrm{L})\end{array}$} & \multirow{2}{*}{$\begin{array}{c}\text { Maximum } \\
(\mu \mathrm{mol} / \mathrm{L})\end{array}$} \\
\hline & & & & & $\begin{array}{l}\text { Lower Bound } \\
(\mu \mathrm{mol} / \mathrm{L})\end{array}$ & $\begin{array}{l}\text { Upper Bound } \\
(\mu \mathrm{mol} / \mathrm{L})\end{array}$ & & \\
\hline 1 & 24 & 9.199 & 4.0682 & .8304 & 7.481 & 10.917 & 3.6 & 22.9 \\
\hline 2 & 32 & 11.947 & 6.2198 & 1.0995 & 9.704 & 14.189 & 5.4 & 32.4 \\
\hline 3 & 24 & 12.512 & 7.1332 & 1.4561 & 9.500 & 15.525 & 4.7 & 30.9 \\
\hline 4 & 20 & 24.065 & 21.5635 & 4.8217 & 13.973 & 34.158 & 4.9 & 102.2 \\
\hline Total & 100 & 13.847 & 12.0395 & 1.2039 & 11.458 & 16.236 & 3.6 & 102.2 \\
\hline
\end{tabular}

Multiple comparisons using Tukey Honest Significant Difference post hoc test showed that the mean fasting homocysteine level had highly significant increase in cases with pregnancy loss of four $(24.07 \pm 21.56 \mu \mathrm{mol} / \mathrm{L})$ as to the women with pregnancy loss of one $(9.20 \pm 4.07 \mu \mathrm{mol} / \mathrm{L})$, two $(11.95 \pm 6.22 \mu \mathrm{mol} / \mathrm{L})$ and three $(12.51 \pm 7.13 \mu \mathrm{mol} / \mathrm{L}), \mathrm{p}<0.001$. However, there was no significant difference in the levels observed among women with one, two or three pregnancy losses (Table 4).

\begin{tabular}{|c|c|c|c|c|c|c|}
\hline \multirow{2}{*}{$\begin{array}{c}\text { Number of } \\
\text { Pregnancy Loss (I) }\end{array}$} & \multirow{2}{*}{$\begin{array}{c}\text { Number of } \\
\text { Pregnancy Loss (J) }\end{array}$} & \multirow{2}{*}{$\begin{array}{c}\text { Mean Difference } \\
(I-J)\end{array}$} & \multirow{2}{*}{$\begin{array}{c}\text { Standard } \\
\text { Error }\end{array}$} & \multirow{2}{*}{$P$ value } & \multicolumn{2}{|c|}{ 95\% Confidence Interval } \\
\hline & & & & & Lower Bound & Upper Bound \\
\hline \multirow{3}{*}{ 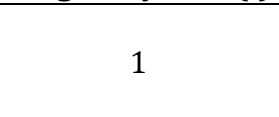 } & 2 & .757 & 1.3121 & .939 & -2.673 & 4.188 \\
\hline & 3 & .704 & 1.4027 & .958 & -2.963 & 4.372 \\
\hline & 4 & 5.048 & 1.4711 & .005 & 1.201 & 8.894 \\
\hline \multirow[t]{3}{*}{2} & 1 & -.757 & 1.3121 & .939 & -4.188 & 2.673 \\
\hline & 3 & -.053 & 1.3121 & 1.000 & -3.483 & 3.378 \\
\hline & 4 & 4.291 & 1.3850 & .013 & .669 & 7.912 \\
\hline \multirow[t]{3}{*}{3} & 1 & -.704 & 1.4027 & .958 & -4.372 & 2.963 \\
\hline & 2 & .053 & 1.3121 & 1.000 & -3.378 & 3.483 \\
\hline & 4 & 4.344 & 1.4711 & .020 & .497 & 8.190 \\
\hline \multirow[t]{3}{*}{4} & 1 & -5.048 & 1.4711 & .005 & -8.894 & -1.201 \\
\hline & 2 & -4.291 & 1.3850 & .013 & -7.912 & -.669 \\
\hline & 3 & -4.344 & 1.4711 & .020 & -8.190 & -.497 \\
\hline
\end{tabular}

The folic acid levels of all the 100 women in the control group had normal levels, whereas in the case group 76 had normal levels and 24 had decreased levels (Figure 2).

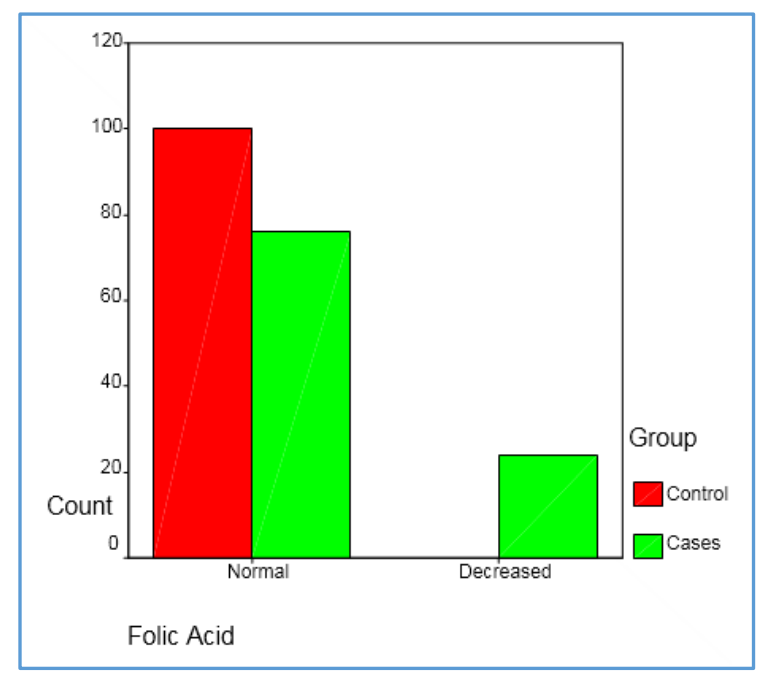

Figure 2. Folic Acid Category

(Normal Level is $2-20 \mathrm{ng} / \mathrm{mL}$, Decreased Levels is $<2 \mathrm{ng} / \mathrm{mL}$ ) 
The analysis by Independent samples t-test showed that the mean folic acid level had significant lowering in patients with pregnancy loss $(11.85 \pm 5.13 \mathrm{ng} / \mathrm{mL})$ as compared to controls $(13.92 \pm 3.73 \mathrm{ng} / \mathrm{mL}), \mathrm{p}<0.001$ (Table 2). There was a statistical difference in the folic acid levels as determined by one-way ANOVA $\mathrm{F}(3,96)=4.772, \mathrm{P}=0.004$ (Table 5).

\begin{tabular}{|c|c|c|c|c|c|c|c|c|}
\hline \multirow{2}{*}{$\begin{array}{l}\text { No. of } \\
\text { Pregnancy } \\
\text { Loss }\end{array}$} & \multirow{2}{*}{$\begin{array}{l}\text { No. of } \\
\text { Cases }\end{array}$} & \multirow{2}{*}{$\begin{array}{c}\text { Mean Folic } \\
\text { Acid Level } \\
\text { (ng/mL) }\end{array}$} & \multirow{2}{*}{$\begin{array}{c}\text { Std. Deviation } \\
\text { (ng/mL) }\end{array}$} & \multirow{2}{*}{ Std. Error } & \multicolumn{2}{|c|}{$\begin{array}{l}\text { 95\% Confidence Interval for } \\
\text { Mean }\end{array}$} & \multirow{2}{*}{$\underset{(\mathrm{ng} / \mathrm{mL})}{\operatorname{Minimum}}$} & \multirow{2}{*}{$\begin{array}{l}\text { Maximum } \\
(\mathrm{ng} / \mathrm{mL})\end{array}$} \\
\hline & & & & & $\begin{array}{l}\text { Lower Bound } \\
\text { (ng/mL) }\end{array}$ & $\begin{array}{l}\text { Upper Bound } \\
\text { (ng/mL) }\end{array}$ & & \\
\hline 1 & 24 & 13.268 & 4.0356 & .8238 & 11.564 & 14.972 & 4.1 & 19.9 \\
\hline 2 & 32 & 12.511 & 5.3019 & .9373 & 10.600 & 14.423 & 3.5 & 19.6 \\
\hline 3 & 24 & 12.564 & 5.0072 & 1.0221 & 10.450 & 14.679 & 3.3 & 19.4 \\
\hline 4 & 20 & 8.221 & 4.8333 & 1.0808 & 5.958 & 10.483 & 2.1 & 16.2 \\
\hline Total & 100 & 11.848 & 5.1291 & .5129 & 10.830 & 12.865 & 2.1 & 19.9 \\
\hline
\end{tabular}

Multiple comparisons by Tukey post hoc test showed that the mean folic acid level was significantly lower in cases with 4 pregnancy losses $(8.22 \pm 4.83 \mathrm{ng} / \mathrm{mL})$ as to the cases with pregnancy loss of one $(13.27 \pm 4.04 \mathrm{ng} / \mathrm{mL})$, two $(12.51 \pm 5.30 \mathrm{ng} / \mathrm{mL})$ and three $(12.56 \pm 5.01 \mathrm{ng} / \mathrm{mL}), \mathrm{p}<0.010$. However, there was no significant difference in the levels observed among women with one pregnancy loss as to two $(p=0.939)$ or three $(p=0.958)$ pregnancy losses and women with three pregnancy losses to women with two pregnancy losses, $\mathrm{p}=1.000$.

\section{DISCUSSION}

The amino acid homocysteine is a transmethylation product of methionine. In a normal healthy pregnancy, the body maintains a lower total plasma homocysteine levels from the very beginning of pregnancy (compared to the pre-conception level) via human chorionic gonadotropin (HCG), haemodilution, enhanced glomerular filtration and through placental hormones. If present in higher plasma concentrations, a condition referred to as hyperhomocysteinaemia $(15 \mu \mathrm{mol} / \mathrm{L})$, it is an indicator of defective reproductive function. Hyperhomocysteinaemia is also associated with poor placental development and foetal malformations such as neural tube defects and congenital heart defects. ${ }^{3}$

In the current study, we observed that the fasting total plasma homocysteine levels were significantly higher in women with pregnancy loss as compared to women with normal pregnancies. $24 \%$ of the women with pregnancy loss had elevated homocysteine levels. The mean levels showed consistent increase with subsequent pregnancy loss and the values were highly significant when the number of pregnancy loss was four. This is in agreement with a study conducted by Maurice GA J Wouters et al (1993), in which they hypothesised elevated homocysteine levels as a probable cause for recurrent pregnancy loss. They observed that 21\% of the women with recurrent pregnancy loss had elevated homocysteine levels and was predominated by parous women (33\% in parous women versus $14 \%$ in nullipara). ${ }^{5}$

The possible mechanism for recurrent pregnancy loss in patients with high homocysteine concentration was explained by a study conducted by Willianne LDM Nelen et al (2000), in which they observed that recurrent early pregnancy loss was associated with decreased blood supply in the chorionic villous. On further evaluation they identified the vessel circumference and the channel width to be less in these patients along with a simultaneous increase in total homocysteine concentration. This was proven using techniques such as CD34 immunohistochemistry combined image analysis and histopathology. ${ }^{6}$ Homocysteine also causes vascular disorders and endothelial dysfunction. This is due to endothelin-1 induction, decreases detoxification reactions and oxidative stress. ${ }^{7}$ In another study conducted by KSD Kumar et al, the assessment of total fasting plasma concentration of homocysteine was found to be higher in case group with pregnancy loss $(10.23 \mu \mathrm{mol} / \mathrm{L})$ versus the control group $(8.95 \mu \mathrm{mol} / \mathrm{L})$, though not statistically significant. ${ }^{8}$

The metabolism of homocysteine is a micronutrient dependent pathway. Folate $(5,10$ methylenetetrahydrofolate), vitamin $\mathrm{B}_{6}$ and $\mathrm{B}_{12}$ play an essential role. Folic acid, a form of folate, is a vitamin belonging to the $\mathrm{B}$ complex family. Hence, a deficiency of folic acid intake can result in deranged metabolism and subsequent accumulation of homocysteine. It is proven that adequate folic acid supplementation also maintains the plasma homocysteine levels in the $1^{\text {st }}$ and $2^{\text {nd }}$ trimester. ${ }^{3}$ Apart from being a component of amino acid metabolism, folic acid is an integral part of DNA synthesis process and erythropoiesis. ${ }^{4}$ Studies also report that folic acid can have an impact on the viability of pregnancy, especially in the initial weeks. ${ }^{9}$

In the current study, we observed $24 \%$ of the women with pregnancy loss have a decrease in serum folic acid levels. The women with recurrent pregnancy loss had a highly significant lower mean folic acid levels as to normal antenatal women. This is in agreement with the study conducted by Audrey J Gaskins et al (2014), who concluded that there was an inverse relation between folate intake and pregnancy loss after an observation that those with a folic acid intake of $<285 \mu \mathrm{g} /$ day had 0.91 relative risk of spontaneous abortions than the woman taking supplements $>851 \mu \mathrm{g} /$ day. ${ }^{10}$

The pregnancy loss occurring in cases of folate deficiency is due to the deregulation of the normal physiological changes i.e. imbalance in intake and increased demand. Invasion of the endovascular trophoblast, vasculature development, elaboration of matrix metalloproteinase and normal placentation has an acknowledgeable dependence on folic acid levels as proposed by William PJ (2011) in his study. ${ }^{8}$ Extensive studies have demonstrated the embryo-protective, foetus-protective and pregnancy sustaining role of folic acid. ${ }^{4}$ The protection role against spontaneous preterm births and placental complications has also been stated in studies. ${ }^{11,12}$

\section{CONCLUSION}

The fasting total plasma homocysteine level was significantly higher and folic acid level was significantly lower in women with pregnancy loss. The difference was more in women who experienced pregnancy loss four times. 


\section{REFERENCES}

[1] Bhattacharya MB, Kamble G. Miscarriage and associated risk factors in India: a brief review. MOJ Womens Health 2017;4(4):00090.

[2] Sztenc S. Hyperhomocysteinemia and pregnancy complications. Ginekol Pol 2004;75(4):317-25.

[3] Makowski G. Advances in clinical chemistry. Vol. 53. Amsterdam: Elsevier/Academic Press 2011. https://books.google.co.in/books?hl=en\&lr=\&id=3Rb qgnZGsoAC\&oi=fnd\&pg=PA105\&dq=homocysteine+a nd+pregnancy\&ots=7a3leMtTOT\&sig=aLGRIn9db5hx $\mathrm{hMvNn} 4 \mathrm{wmliyrr} 8 \mathrm{M} \# \mathrm{v}=$ onepage $\& \mathrm{q}=$ homocysteine $\% 2$ 0and\%20pregnancy\&f=false

[4] Greenberg JA, Bell SJ, Guan Y, et al. Folic acid supplementation and pregnancy: more than just neural tube defect prevention. Rev Obstet Gynecol 2011;4(2):52-9.

[5] Wouters M, Boers G, Blom HJ, et al. Hyperhomocysteinemia: a risk factor in women with unexplained recurrent early pregnancy loss. Fertil Steril 1993;60(5):820-5.

[6] Nelen W, Bulten J, Steegers EA, et al. Maternal homocysteine and chorionic vascularization in recurrent early pregnancy loss. Hum Reprod 2000;15(4):954-60.
[7] Cheng Z, Yang X, Wang H. Hyperhomocysteinemia and endothelial dysfunction. Curr Hypertens Rev 2009;5(2):158-65.

[8] Kumar KS, Govindaiah V, Naushad SE, et al. Plasma homocysteine levels correlated to interactions between folate status and methylene tetrahydrofolate reductase gene mutation in women with unexplained recurrent pregnancy loss. J Obstet Gynaecol 2003;23(1):55-8.

[9] Gaskins AJ, Rich-Edwards JW, Hauser R, et al. Maternal prepregnancy folate intake and risk of spontaneous abortion and stillbirth. Obstet Gynecol 2014;124(1):23-31.

[10] Williams PJ, Bulmer JN, Innes BA, et al. possible roles for folic acid in the regulation of trophoblast invasion and placental development in normal early human pregnancy. Biol Reprod 2011;84(6):1148-53.

[11] Bukowski R, Malone FD, Porter FT, et al. Preconceptional folate supplementation and the risk of spontaneous preterm birth: a cohort study. PLoS Med 2009;6(5):e1000061.

[12] Wen SW, Zhou J, Yang Q, et al. Maternal exposure to folic acid antagonists and placenta-mediated adverse pregnancy outcomes. CMAJ 2008;179(12):1263-8. 